\title{
PENGARUH PENGGUNAAN ELASTIC LUMBAL CORSET TERHADAP PENURUNAN DERAJAT NYERI PINGGANG PADA BURUH TANI DI DESA TINAWAS NOGOSARI BOYOLALI
}

\author{
Cica Tri Mandasari Ningsih, Dwi Setyawan, Lathifatul Baroroh \\ Politeknik Kesehatan Surakarta Jurusan Ortotik Prostetik
}

\begin{abstract}
Back Pain, Pain, Lumbar Elastic Corset. The research was purposed to determine the effect of the use of elastic lumbar corset against degradation of low back pain in farm workers. The low back pain is pain that occurs in the area of the lower back and can spread to the foot, especially the back and sides outside. Giving elastic lumbar corset is one way to deal with complaints of back pain is often experienced farm workers. The subjects included 20 farm laborers in the village Tinawas Nogosari Boyolali. To analyze the data, it use quasi experiment methode with approaches one group pre and post test design. The statistical analysis using non-parametric tests of hypotheses for subjects $<30$ using Wilcoxon test. The Treatment in this research that the whole subject is applied elastic lumbar corset for 2 weeks. The result showed that the VAS values of different test results using Wilcoxon test, the pre and post test result $p=$ 0.000 (<0.05), which means it can be concluded there is peberbedaan or significant influence between before and after the use of elastic corset. So, the hypothesis proposed in this research was accepted. In conclusion, it can be said that pain management waist on a farm laborer using elastic lumbar corset can reduce pain she felt every day on a farm laborer in the village Tinawas Nogosari Boyolali.
\end{abstract}

Keywords : Back Pain, Pain, Lumbar Elastic Corset

Abstrak : Nyeri Pinggang, Nyeri, Elastic Lumbal Corset. Untuk mengetahui
pengaruh penggunaan elastic lumbal corset terhadap penurunan derajat nyeri pinggang
pada buruh tani. Nyeri pinggang merupakan rasa nyeri yang terjadi di daerah punggung
bagian bawah dan dapat menjalar ke kaki terutama bagian belakang dan samping luar.
Pemberian elastic lumbal corset adalah salah satu cara untuk mengatasi keluhan nyeri
pinggang yang sering dialami buruh tani. Subyek penelitian berjumlah 20 buruh tani di
desa Tinawas Nogosari Boyolali. One group pre and post test design. Seluruh subyek
diberikan perlakuan yang sama. Analisa statistik dengan menggunakan uji hipotesis non
parametrik karena subjek < 30 yaitu menggunakan uji wilcoxon. Seluruh subyek
dipakaikan elastic lumbal corset. Hasil uji beda nilai VAS menggunakan uji wilcoxon,
pada pre dan post tes diperoleh hasil p $=0,000$ (<0,05). Terdapat pengaruh pemakaian
elastic lumbal corset terhadap penurunan derajat nyeri pada buruh tani di desa Tinawas
Nogosari Boyolali.

Kata Kunci : Nyeri Pinggang, Nyeri, Elastic Lumbal Corset 


\section{PENDAHULUAN}

Indonesia sebagai Negara agraris, dimana mayoritas masyarakat di Indonesia adalah berprofesi sebagai petani. Fenomena di Indonesia, petani menghabiskan waktu setiap harinya di sawah, walaupun hanya untuk mengawasi sawah ataupun mencangkul dan menanam. Pekerjaan seperti itu dilakukan secara terus-menerus oleh buruh tani sebagai rutinitas.

Buruh tani adalah seseorang yang bergerak di bidang pertanian, utamanya dengan cara melakukan pengelolaan tanah dengan tujuan untuk menumbuhkan dan memelihara tanaman (seperti padi, jagung, buah dan lain-lain), dengan harapan untuk memperoleh hasil dari tanaman tersebut untuk digunakan sendiri atau menjualnya kepada orang lain (Husodo SY, 2004).

Menurut penelitian, pekerjaan manual handling dan lifting merupakan penyebab utama terjadinya cedera tulang belakang (back pain). Di samping itu sekitar 25\% kecelakaan kerja juga terjadi akibat pekerjaan material manual handling. Sebelumnya dilaporkan bahwa sekitar $74 \%$ cedera tulang belakang disebabkan oleh aktivitas mengangkat (lifting activities). Sedangkan $50-60 \%$ cedera pinggang disebabkan karena aktivitas mengangkat dan menurunkan material (Tarwaka, 2004)

Tujuan penelitian ini adalah untuk mengetahui pengaruh penggunaan elastic lumbal corset terhadap penurunan derajat nyeri pinggang pada buruh tani

Nyeri merupakan kondisi yang lebih dari sekedar sensasi tunggal yang disebabkan oleh stimulus tertentu. Nyeri bersifat subjektif dan sangat bersifat individual. Stimulus nyeri dapat berupa syimulus yang bersifat fisik atau mental, sedangkan kerusakan dapat terjadi pada jaringan actual atau pada fungsi ego seorang (Potter \& Perry, 2005).

Nyeri berdasarkan derajatnya dikelompokkan menjadi 3 yaitu: a) nyeri ringan adalah nyeri hilang timbul, terutama saat beraktivitas sehari hari dan menjelang tidur, b) Nyeri sedang adalah nyeri terus-menerus, aktivitas terganggu yang hanya hilang bila penderita tidur, c) Nyeri berat adalah nyeri terus menerus sepanjang hari, penderita tidak dapat tidur dan sering terjaga akibat nyeri Insiden nyeri pinggang di masyarakat, diperkirakan $60 \%-85 \%$ dari populasi seluruh dunia pernah merasakan nyeri punggung bawah semasa hidupnya (Elders, 2003).

Sedangkan nyeri pinggang atau low back pain (LBP) adalah rasa nyeri pinggang muskulosketal yaitu sindroma klinik yang ditandai adanya rasa nyeri atau perasaan lain yang tidak enak didaerah tubuh bagian belakang dari rusuk terakhir vetebra torakal 12 sampai bagian bawah pantat atau anus dan dapat menjalar ke kaki terutama bagian belakang dan samping luar. Tulang belakang manusia terdiri dari 33 ruas tulang. Satu sama lain dihubungkan oleh sistem yang unik, terdiri atas tulang rawan, otot serta jaringan ikat. Sistem itu bekerja sama untuk mempertahankan tubuh pada posisi tegak. Gangguan pinggang biasanya berhubungan dengan tiga ruas tulang pinggang atau dengan organ di sekitarnya seperti ginjal dan indung telur. (Suzilawat, 2006:1).

Pada dasarnya timbulnya rasa sakit pinggang terjadi karena ada penekanan pada susunan saraf tepi daerah pinggang (syaraf terjepit). Jepitan pada syaraf ini dapat terjadi karena gangguan pada otot pada jaringan sekitarnya, gangguan pada syaraf sendiri, kelainan tulang belakang 
maupun kelainan di tempat lain. (Pearce, 1999).

Timbulnya nyeri pinggang erat kaitannya dengan cara kerja, sikap kerja, dan posisi kerja, desain alat kerja, fasilitas kerja, tata letak, sarana kerja dan sebagainya. Dengan memperhatikan dan menata faktor-faktor penyebab dan pencetusnya, insiden nyeri pinggang kerja dapat dieliminir atau di tunda kehadirannya. Bebarapa faktor kaitan dengan beban angkat-angkat yang mempengaruhi timbulnya nyeri pinggang kerja adalah berat beban, besar beban, bentuk beban, jenis beban, tinggi beban, dan sebagainya. (Depnaker, 1995).

Etiologi Nyeri Pinggang disebabkan oleh berbagai kelainan atau perubahan patologi yang mengenai berbagai macam organ. Beberapa ahli membuat klasifikasi yang berbeda atas dasar kelainan atau jaringan yang mengalami kelainan tersebut. Rasa sakit dapat ditimbulkan oleh segala sesuatu yang menekan atau menegangkan syaraf pada tubuh bagian belakang dan di otot-otot. Menurut Audre L (2003) secara garis besar faktor penyebab nyeri pinggang dapat dibedakan menjadi :

a. Sakit pinggang akibat sikap yang salah. Posisi tubuh yang tidak tepat pada saat bekerja karena kursi yang digunakan tidak ergonomis. (Nadesul, 2002).

b. Sakit pinggang pada kelainan tulang belakang. Dapat disebabkan antara lain: cidera, infeksi, tumor, dan osteoporosis.

c. Sakit pinggang pada penyakit organ dalam tubuh Yang sering dijumpai adalah sakit pinggang akibat penyakit prostate, batu ginjal, penyakit lambung, kandungan. Sakit pinggang pada penyakit rematik antara lain: Osteoaritis, rematoid dan arthritis. d. Karena Penyakit Reumatik.

e. Karena Ketegangan Otot (Psikis). Keadaan seperti ini disebut dengan nyeri pinggang psikogenetik. Seperti tekanan mental ataupun pikiran yang berlebihan dapat menyebabkan tulang belakang mengencang dan kaku serta nyeri.

Penanganan nyeri punggung bawah Oleh karena penyebab nyeri pinggang sangat beraneka ragam maka tatalaksananya juga bervariasi. Namun dikenal 2 tahapan yaitu konservatif dan operatif. Kedua tahapan terapi tersebut mempunyai kesamaan tujuan ialah rehabilitasi (Harsono, 2009).

a. Terapi konservatif atau terapi non bedah, Meliputi rehat baring atau istirahat, obat-obatan (medikamentosa), pemberian injeksi local, terapi fisik atau fisioterapi, pemakaian korset atau brace.

b. Terapi operatif atau terapi bedah Dilakukan jika tindakan konservatif tidak memberikan hasil yang nyata terhadap kasus fraktur yang langsung mengakibatkan defisit neurologik.

Penanganan nyeri punggung bawah secara umumnya bervariasi mengikut studi, jenis-jenis pekerjaan, dan persekitaran local. Biasanya dalam kondisi biasa nyeri tersebut akan hilang dengan sendirinya selepas beberapa hari tanpa memerlukan pengobatan, tetapi tidak selalu (Jellema, dkk 2001).

Salah satu alat bantu untuk penanganan nyeri pinggang adalah menggunakan orthosis. Orthosis/Orthose/ ortesa adalah segala alat yang ditambahkan ke tubuh atau alat bantu penyangga tubuh atau anggota gerak tubuh yang layu, Iumpuh atau cacat untuk 
menstabilkan atau immobilize bagian tubuh, mencegah kecacatan, melindungi dari luka, atau membantu fungsi dari anggota tubuh. Salah satu alat orthose tersebut ialah Elastic Lumbal Corset. Elastic Lumbal Corset merupakan alat pelindung diri akibat kerja yang mencegah terjadinya cidera pada jaringan otot saat melakukan aktifitas.

Elastic Lumbal Corset sendiri terbuat dari bahan elastis dan berpori sehingga tidak panas saat dipakai, dan diberi support atau penyangga pada bagian belakang berupa plat almunium pada kedua sisi vertebra dengan panjang $30-40 \mathrm{~cm}$. Untuk ukuran Corset lumbal bervariasi, ada ukuran $\mathrm{S}$ dengan lingkar perut 75-90 cm, ukuran $\mathrm{M}$ dengan lingkar perut 90-105 cm, ukuran L dengan lingkar perut 105-115 cm (Ichwandari,2007).

Desain Elastic Lumbal Corset Lumbal corset terbuat dari bahan elastis dengan lebar pada bagran posterior $25 \mathrm{~cm}$, dan panjang disesuaikan dengan ukuran lingkar perut. Pada bagian posterior diperkuat dengan 4 buah bar metal yang berfungsi sebagai support bagian posterior lumbal.

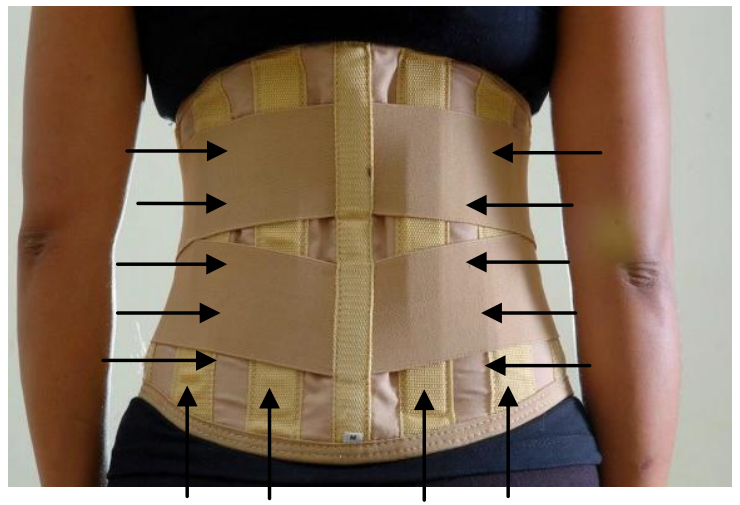

Keterangan gambar:

Anak panah berwarna hitam dari arah lateral ke medial berarti Elastic Lumbal Corset total kontak dengan pasien, sehingga penekanan merata keseluruh bagian. Pada anak panah dari arah distal ke proksimal menunjukkan terdapat 4 buah bar yang berfungsi menopang lumbal, dan juga sebagai stabilisasi pergerakan dari vertebra.

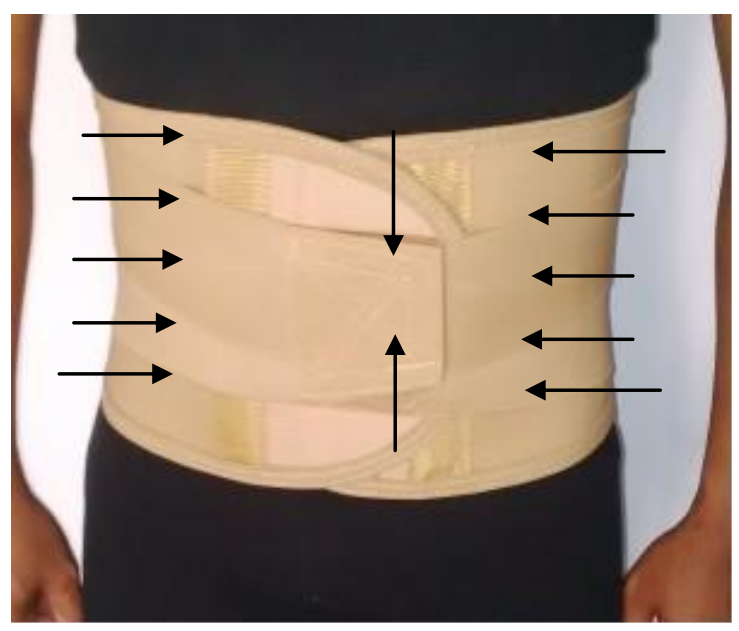

Keterangan gambar:

Anak panah yang berada disamping dari arah lateral ke medial berarti elastic lumbal corset total kontak dengan pasien, sehingga penekanan merata keseluruh bagian. Pada anak panah yang berada dianterior menunjukkan terdapat perekat yang akan menekan abdominal sehingga vertebrae bisa tetap vertikal seta menopang vertebrae saat melakukan pergerakan serta melawah gaya yang ada di bagian posterior.

Dalam penggunaan lumbal corset harus diposisikan secara benar yaitu mengikuti lingkar abdominal sehingga dengan adanya penopang/penekanan di sekitar lumbal akan mengurangi area pembebanan pada corpus lumbal serta adanya penekanan hidrostatis yang berperan membantu memberikan posisi yang stabil sehingga akan mengurangi rasa nyeri pada area lumbal.

Desain elastic lumbal corset produk ortotis prostetis dirancang dengan 
memperhatikan struktur anatomi dan biomekanik tubuh khususnya pada level lumbal, dimana metal/plat bagian posterior didesain dengan tujuan untuk mensupport lumbal disesuaikan dengan kasusnya. Namun demikian dalam pemakaian elastic lumbal corset yang berlebihan dan berlangsung dalam waktu yang lama akan menyebabkan terjadinya kelemahan otot area lumbal dan pasien akan menjadi ketergantungan terhadap pemakaian lumbal corset tersebut. Sehingga pasien juga harus menjalani terapi selain memakai lumbal corset sehingga terjadinya kelemahan otot area lumbal dapat di minimalisir.

\section{METODE PENELITIAN}

Jenis penelitian ini menggunakan metode pre-eksperimen dengan rancangan one group pre-test and post test. Dalam penelitian digunakan satu kelompok yang diteliti tanpa adanya kelompok pembanding, dengan jumlah sampel penelitian sebanyak 20 orang.

01 ------------------- X ----------------- 02

Selanjutnya dilakukan pretest untuk mengetahui derajat nyeri dengan skala VAS dan lembar pencatat hasil, kemudian diberikan perlakukuan untuk menggunakan elastic lumbal corset selama 2 minggu berturut-turut, tanpa melepasnya kecuali pada saat tidur dan mandi.

Setelah dua minggu berakir tanpa control, kemudian dilakukan post test dengan mengukur derajat nyeri setelah menggunakan elastic lumbal corset.

Populasi pada penelitian ini adalah semua buruh tani yang ada di area persawahan di Desa Tinawas Nogosari Boyolali. Sedangkan Sampel peneliti akan mengambil 20 subjek penderita nyeri pinggang di area persawahan di Desa Tinawas Nogosari Boyolali dan besarnya sampel ditentukan oleh purposive sampling. Teknik ini dilakukan karena beberapa pertimbangan, misalanya keterbatasan waktu, tenaga dan dana sehingga tidak dapat mengambil sampel yang besar dan jauh.

Alat ukur pada penelitian penderita nyeri pinggang dengan menggunakan lumbal corset adalah visual analogue scale (VAS). VAS adalah suatu garis yang mewakili intensitas nyeri yang terus menerus dan pendeskripsi verbal pada setiap ujungnya. Skala ini memberikan subyek kebebasan penuh untuk mengidentifikasi keparahan nyeri. VAS dapat merupakan pengukuran keparahan nyeri yang lebih sensitive karena subyek mengidentifikasi setiap titik pada rangkaian dari pada dipaksa memilih kata atau satu angka (Potter, 2005). VAS merupakan garis lurus horizontal dengan panjang $10 \mathrm{~cm}$ dengan ujung sebelah kiri diberi tanda 0 untuk tidak ada rasa sakit dan ujung sebelah kanan diberi tanda dengan angha 10 untuk nyeri yang teramat berat. Intensitas nyeri yang dinilai dengan VAS dengan kategori 0 tidak nyeri sama sekali, $\leq 3$ termasuk nyeri ringan, $\leq 7$ termasuk nyeri sedang, $\geq 8$ termasuk nyeri berat (Smeltzer, S.C bace B.G,2002).

Teknik pengumpulan data pada penelitian ini sebagai berikut; dari suatu populasi didapatkan subyek dengan metode pengambilan data purposive sampling, subyek yang dilakukan pengukuran nyeri sebelum memakai elastic lumbal corset dengan menggunakan alat ukur VAS sebagai pengambilan data pre test. Setelah itu diberi perlakuan dengan menggunakan lumbal corset. Setelah subyek memakai elastic lumbal corset, kemudian dilakukan pengukuran nyeri saat pemakaian elastic lumbal corset dengan menggunakan alat 
ukur VAS sebagai pengambilan data post test. Selanjutnya akan didapat data dan dilakukan analisis data, dari situ akan didapat hasil apakah ada pengaruh pemakaian elastic lumbal corset.

Data yang sudah direkapitulasi untuk hasil pengukuran derajat nyeri pada low back pain baik sebelum dan sesudah dilakukannya perlakuan, kemudian dilakukan analisis data secara statistik sebagai berikut :

1. Uji normalitas

Uji normalitas data digunakan untuk mengetahui apakah data berdistribusi normal atau tidak. Uji normalitas menggunakan Shapiro-Wilk test jika subjek $\leq 30$. Jika subyek $\geq 30$, maka uji normalitas menggunakan Kolmogorov- Smirnov . Data dikatakan berdistribusi normal jika nilai p> 0,05. Apabila data berdistribusi normal, maka menggunakan analisis parametrik. Jika data tidak berdistribusi normal, maka menggunakan analisis non parametrik.

2. Uji beda pre dan post test

Uji Beda pre dan post test digunakan untuk mengetahui hasil perbedaan derajat nyeri pada saat sebelum dan sesudah mendapatkan perlakuan. Kelompok sebelum dan sesudah perlakuan merupakan kelompok data berpasangan dan 2 kelompok. Jika data berdistribusi normal, maka analisis statistik yang digunakan adalah dependent $t$ test. Tetapi Jika data tidak berdistribusi normal, maka analisis statistik yang digunakan adalah Wilcoxon. Jika $\mathrm{P}<0,05$ maka data terpenuhi dan jika $\mathrm{P}>0,05$ maka tidak terpenuhi.

\section{HASIL PENELITIAN}

Subyek dalam penelitian ini adalah buruh tani di desa Tinawas Nogosari Boyolali yang mengalami nyeri pinggang yang kami teliti selama 29 Januari 2016 sampai dengan 25 Maret 2016 yang memenuhi kriteria inklusi dan eksklusi. Jumlah subyek yang memenuhi kriteria inklusi dan eksklusi adalah 20 pasien. Dari 20 responden yang diteliti sebagian besar mempunyai jenis kelamin laki-laki sebesar 13 orang $(65 \%)$ dan perempuan sebesar 7 orang $(35 \%)$.

Berikut didapat hasil deskriptif statistik

Tabel 1

Hasil Deskriptif Statistik

\begin{tabular}{lcc}
\hline & VAS Pre Test & VAS Post Test \\
\hline Minimum & 6 & 2 \\
Maksimum & 9 & 4 \\
Rerata & 7,8 & 2,75 \\
Standar & 0,834 & 0,639 \\
Deviasi & \\
\hline
\end{tabular}

Dari table 1 deskriptif statistic diketahui nilai rerata pada Pre Test dan Post Test mengalami penurunan angka, yang berarti setrelah diberi perlakuan Elastis Lumbal Corset selama dua minggu.

Berikut didapatkan hasil uji prasyarat

Tabel 2

Data Hasil Uji Normalistas ShapiroWilk

\begin{tabular}{llll}
\hline & \multicolumn{3}{c}{ Shapiro-Wilk } \\
& Statistic & $\begin{array}{c}\text { Jumlah } \\
\text { data }\end{array}$ & $\begin{array}{l}\text { Signifikansi } \\
(\mathrm{p})\end{array}$ \\
\hline $\begin{array}{l}\text { VAS Pre } \\
\text { Test }\end{array}$ & 0,873 & 20 & 0,013 \\
$\begin{array}{l}\text { VAS Post } \\
\text { Test }\end{array}$ & 0,78 & 20 & 0,000 \\
\hline
\end{tabular}

Dari table 2 hasil uji normalitas Shapiro-wilk pada kelompok VAS Pre Test didapat nilai Shapiro-wilk $=0,013$, dengan $\mathrm{p}=0,013$. Karena $\mathrm{p}>0,05$ maka distribusi data dikatakan tidak normal

Dari uji normalitas pada kelompok VAS Post Test didapat nilai Shapiro-wilk $=0,780$, dengan $\mathrm{p}=0,000$. Karena $\mathrm{p}>0,05$ 
maka distribusi data dikatakan tidak normal.

Subyek yang digunakan pada penelitian ini berjumlah 20 orang, maka untuk uji statistik dalam menganalisis data menggunakan uji statistik non parametrik menggunakan uji wilcoxon. Berikut ini adalah hasil uji statistik untuk menjawab hipotesis dalam penelitian ini.

Tabel 3

\section{Statistik Wilcoxon Test}

\begin{tabular}{|c|c|}
\hline & Post Test- Pre Test \\
\hline $\mathrm{Z}$ & -3.981 \\
\hline Asymp. Sig. (2-tailed) & .000 \\
\hline
\end{tabular}

Wilcoxon test didapat hasil pada VAS post test dan Vas pre test nilai $\mathrm{p}=0,000$ $(<0,05)$, yang berarti dapat disimpulkan terdapat peberbedaan atau pengaruh yang bermakna antara sebelum dan sesudah penggunaan Elastic Lumbal Corset.

\section{PEMBAHASAN}

Dari hasil penelitian diatas menunjukkan bahwa ada pengaruh pemakaian elastic lumbal corset terhadap penurunan nyeri pinggang setelah responden menggunakan Elastis lumbal Corset pada saat aktifitas bertani selama dua minggu.

Hal tersebut sesuai dengan teori yang sudah dibahas oleh peneliti pada bab sebelumnya, bahwa pemakaian orthosis atau alat bantu pada penanganan nyeri pinggang sangat efektif. Dengan cara kerja orthosis dengan pemakaian yang tepat, masing-masing bagian akan bekerja secara maksimal. Bagian posterior elastis lumbal corset berkontak secara penuh dengan vertebrae pasien sehingga bisa memberi support pada lumbal yang akan mengurangi beban pada corpus lumbal serta adanya penekanan hidrostatis yang berperan membantu memberikan posisi yang stabil sehingga akan mengurangi rasa nyeri pada area lumbal. Pada elastis lumbal corset pada bagian anterior terdapat perekat yang akan menekan abdominal sehingga vertebrae bisa tetap lurus dan menopang vertebrae saat melakukan pergerakan serta melawah gaya yang ada di bagian posterior.

Hal tersbut juga dibuktikan pada penelitian sebelumnya oleh penelitian Alfan Zubaidi dkk (2012) dan Rendra Gita Aulia (2012) menyimpulkan bahwa adanya pengaruh penggunaan elastic lumbal corset dan korset dengan bahan dasar support bamboo terhadap penurunan derajat nyeri sesuai dengan hasil penelitian yang peneliti lakukan.

Adapun factor yang mempengaruhi subyek penelitian melakukan aktivitas di sawah kurang lebih 6-7 jam perhari dan berpindah dari area persawahan satu ke area persawahan lain. Pekerjaan tersebut berpengaruh dalam factor resiko terjadinya nyeri pinggang, yaitu secara factor pekerjaan adalah

1) beban kerja, buruh tani berkerja mengangkat cangkul hampir setiap hari untuk menggali tanah disawah

2) lama kerja, buruh tani melakukan aktivitas yang cukup lama di area persawahan dan kadang dilakukan setiap hari senin-minggu karena banyak buruh tani yang tidak hanya menggarap satu sawah

3) sikap kerja, sikap kerja ini yang paling cenderung menyebabkan terjadinya nyeri pinggang karena aktivitas pasien lebih sering berdiri dan membungkuk dalam waktu yang lama, apalagi saat sedang musim tanam.

Selain dari faktor pekerjaan, masih ada pula faktor personal yang menyebabkan terjadinya nyeri pinggang, antara lain 
1) Usia, usia kerja pada umumnya $25-65$ tahun. Dan semakin berusia maka semakin kekuatan dan ketahanan otot mulai menurun, sehingga resiko terjadinya keluhan otot untuk nyeri pinggang meningkat. Subyek yang digunakan dalam penelitian ini adalah subyek yang termasuk dalam kategori usia tenaga kerja, hal ini dilakukan agar hasil dari penelitian lebih obyektif karena menggunakan satu kategori umur yang sama

2) Masa kerja, subyek yang termasuk dalam inklusi, sudah bekerja sebagai buruh tani selama lebih dari 5 tahun. Menurut Between Lutam (2005) mengatakan pekerja yang memiliki masa kerja > 5 tahun memiliki tingkat resiko 7,26 kali lebih besar menderita nyeri pinggang dibanding dengan yang memiliki masa kerja $<5$ tahun

3) jenis kelamin, kekuatan fisik tubuh wanita rata-rata $2 / 3$ dari pria. Poltras menyebutkan wanita mempunyai kekuatan $65 \%$ dalam mengangkat di banding rata-rata pria.

\section{KESIMPULAN DAN SARAN}

Penelitian yang berjudul pengaruh penggunaan elastic lumbal corset terhadap penurunan derajat nyeri pinggang pada buruh tani di Desa Tinawas Nogosari Boyolali yang dilakukan pada tanggal 29 Januari - 25 Maret 2016 didapatkan 20 buruh tani di Desa Tinawas Rembun Nogosari yang mengalami nyeri pinggang.

Penelitian ini menggunakan dua kali analisis data yaitu uji normalitas dan uji hipotesis. Pada uji normalitas menggunakan Shapiro-wilk untuk kondisi sebelum dan sesudah penggunaan elastic lumbal corset didapatkan hasil bahwa data berdistribusi tidak normal. Pada uji hipotesis menggunakan Wilcoxon untuk kondisi sebelum dan sesudah penggunaan elastic lumbal corset didapatkan hasil nilai $\mathrm{p}=0,000(<0,05)$.

Berdasarkan analisis yang telah dilakukan, kesimpulan dari penelitian ini adalah penanganan nyeri pinggang pada buruh tani menggunakan elastic lumbal corset dapat mengurangi rasa nyeri yang dirasakannya setiap hari dan factor resiko yang berperan secara signifikan untuk terjadinya nyeri pinggang pada buruh tani adalah sikap atau postur kerja buruh tani yang tidak ergonomis dalam membungkuk, punggung membungkuk, punggung berputar, punggung miring, berjongkok, besarnya gaya, lamanya waktu kerja.

Mengingat kelemahan yang ada pada penelitan ini, disarankan untuk dilakukan penelitian lanjut dengan memperhatikan: (1) subyek penelitian yang lebih banyak, (2) menggunakan tambahan kelompok untuk pembanding, (3) melakukan penelitian dengan menggunakan metode lain agar lebih akurat.

\section{DAFTAR PUSTAKA}

Alfan Zubaidi, 2012; Keefektifan Elastic Lumbal Corset Terhadap Progresivitas Derajat N Yeri Pada Pasien Low Back Pain, Kementrian Kesehatan Politektik Kesehatan Surakarta Jurusan Ortotik Prostetik, Surakarta.

Arikunto, Suharsini. 2002; Prosedur Penelitian Suatu Pendekatan Praktik Jakarta, PT. Rineka Cipta.

Astuti, Rahmaniyah Dwi, 2007; Analisa Pengaruh Aktivitas Kerja Beban Angkat Terhadap Keluhan Musculoskeletal.

Aulia M.H., Rendra Gita, 2012; Model Korset Dengan Bahan Dasar 


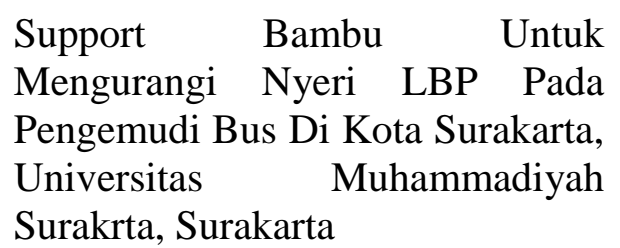

A.M. Sugeng Budiono. 2003. Bunga Rampai Hiperkes dan Kesehatan Kerja. Universitas Diponegoro, Semarang.

Budger, R.S., 1995; Introduction to Ergonomic, International Conference on Production Research, Singapore

Deli Sulvici Sitepu, 2015; Faktor-Faktor Yang Berhubungan Dengan Keluhan Low Back Pain Pada Petani Jeruk di Desa Dokan Kecamatan Merek Kabupaten Karo Tahun 2015, Universitas Sumatera Utara, Medan.

Depnaker, 1993; Data Antropometri Statis (A) tenaga kerja Indonesia pria dan wanita dari beberapa perusahaan di Indonesia tahun 1992-1993, Depnaker, Jakarta.

Elders LAM, Burdoff A, 2003; Prevalence incidence and recurrence of low back pain in Scaffolders during a three year follow up study; In : Elders LAM, ed work related musculoskeletal disorder in Scaffolders, Rotterdam.

Husodo, S.Y., 2004, Pertanian Mandiri: Pandangan Strategis Para Pakar Untuk Kemajuan Pertanian Indonesia, Penerbar Swadaya, Jakarta.

Ichwandari. Ida Laksmi,2007; Perbedaan Pengaruh Antara Pemberian Lumbal Corset dan Back Exercise Dengan Back Exercise Terhadap Penurunan Nyeri Punggung Bawah di Poliklinik Fisioterapi Rumah Sakit Umum Daerah Kabupaten

\author{
Sragen, \\ Universitas \\ Muhammadiyah \\ Surakarta, \\ Surakarta \\ Jellema, Van Tulder M.W., dkk, 2001, \\ Lumbar Support For Prevention \\ And Treatment OF Low Back \\ Pain, Spine.
}

Llewellyn, V, 2006; Back and Neck related Condition, Institute of Actuaries of Australia. Sidney.

Long, B.C, 1996; Peranatan Medikal Bedah, Alih Bahasa YIA PKP, Yayasan IAPK Pajajaran, Bandung.

Lutam, Between. 2005; Analisis Nyeri Punggung Dengan Faktor-faktor yang Berhubungan Pada Pekerja Wanita Di Penjahitan Pakaian PT. X Gunung Putri Bogor 2005, Fakultas Kedokteran Universitas Indonesia, Jakarta.

Muheri. A, 2010; Hubungan Usia, Lama Duduk dan Posisi Duduk Terhadap Keluhan Nyeri Punggung Pada Pekerja Wanita di Home Industri Kipas Desa Bayon Utara Pendowoharjo Sewon Bantul 2010, Bantul.

Samara.D, 2005; Duduk Statis Sebagai Faktor Risiko Teradinya Nyeri Punggung Bawah Pada Pekerja Perempuan, Universa Medicina Trisakti, Jakarta 